\title{
TEA PESTS AND PESTICIDE PROBLEMS AND INTEGRATED MANAGEMENT
}

Gita Shrestha \& Resham B. Thapa ${ }^{11}$

\section{ABSTRACT}

Tea is one of the most popular beverage and main cash crops of Nepal with a very high export potential. Its plantation has expanded over 19000 ha with production of nearly 21 million kg per annum providing employment opportunity to 12000 farmers and many traders in Nepal. This plant suffers from more than 300 recognized pests, of which 25-30 insect pests occur regularly in poorly managed tea garden and some of them are major ones causing significant crop loss. Their recognition of field occurrence and incidence helps in devising management options to reduce crop loss. Therefore, a study was conducted to monitor insect pests, ascertain their nature of incidence and time of occurrence in tea garden in terai (Bhadrapur), foot-hill (Barne) and mid- hill (Kanyam) of eastern Nepal. Information was gathered by interacting with local tea gardeners, close observation in the field, collection of species and their identification in the laboratory, which showed that both terai and foot-hills with warmer climate harbored higher number of species than mid-hills. Their integrated management is essential for sustainable tea production.

Key words: Tea insect pests, field incidence, integrated management

\section{INTRODUCTION}

Tea is the oldest known beverage, native to China. It is one of the important plantation crops in the world. Its cultivation, processing and trade is expanding globally. The industry has grown globally into a $\$ 20$ billion (Kahn, 2015). Annually over 2.6 million $\mathrm{mt}$ of tea is consumed in more than 65 countries, where people drink some 4 billion cup of tea brew daily (Jain, 2001). It is an important commodity of international trade and it is also a cash crop and important export item of Nepal. Yield potential of tea has been estimated at 25,000 kg made tea per hectare per year with uniform weekly harvest. Nepalese tea, due to its unique flavor and aroma, is popular in domestic as well as international market. Tea industry and related trade provides employment and income to many people.

Research indicates that tea growing regions could decline in some parts of the world by up to 40 to 55 percent in the coming decades (Kahn, 2015). The productivity is declining due to unusual weather and large number of insect pests and diseases. About $5-10 \%$ crop loss has been estimated due to pest incidence, while crop loss has been increasing at present, which is as high as 15-25\% (Sinha, 2010). Pest damage in China, decreased the yield by 10 $20 \%$ in an average a year (Yongming, 1999). Mamun and Ahmed (2011) reported 10-15\% loss in normal condition and as high as $100 \%$ in severe cases. It is even higher in Nepal due to indiscriminate use of pesticides. Therefore, it was necessary to study tea production scenario and insect pests through monitoring tea garden and identify their damage for better management to increase production/productivity of quality tea.

\footnotetext{
${ }^{1}$ Mechi Multiple Campus, and Institute of Agriculture and Animal Science, TU, Nepal
} 


\section{METHODOLOGY}

This study was done in three topographical domains- terai plain (Bhadrapur Tea Garden), foot hills (Barnae Tea Estate), and mid hill (Kanyam Tea Garden). Periodic field visits, field survey and monitoring of insect pests, sample collection and identification of the pests were done during the tea flushing seasons. Standard insect collecting net was used to sweep in the tea garden. Thirty sweeping from each site were collected separately, brought in lab, sorted out and identified. In addition, visual observation was done in the field to see their feeding damage and also discussed with the local tea farmers for management. Additional information were gleaned through available literature tea production and integrated management of tea insect pests prepared for farmers IPM practices.

\section{RESULTS AND DISCUSSION}

Tea production trend: The total acreage and production of tea in Nepal is presented in Table 1. Both private companies and small holder farmers are involved in tea gardening. Tea plantation has expanded over 19000 ha with production of nearly 21 million kg per annum providing employment opportunity to nearly 12000 farmers and many traders. Tea plant has deep root system and so holds the soil strongly and contributes to soil conservation in hilly area of Nepal. Hence, plantation contributes to raise farmers' livelihood through employment generation and to national AGDP with its national and international trade.

Table 1. Plantation and production trend of tea in Nepal (2001-2013)

\begin{tabular}{|c|c|c|c|c|c|c|c|}
\hline \multicolumn{5}{|c|}{ Tea Plantation (ha) } & \multicolumn{3}{|c|}{ Tea Production (kg) } \\
\hline \multirow[t]{2}{*}{$F Y$ in $A D$} & \multirow[t]{2}{*}{ Private } & \multicolumn{2}{|c|}{ Small Holders } & \multirow[t]{2}{*}{ Total } & \multirow[t]{2}{*}{ Private } & \multirow{2}{*}{$\begin{array}{c}\text { Small } \\
\text { Holder }\end{array}$} & \multirow[t]{2}{*}{ Total } \\
\hline & & Farmers & Area & & & & \\
\hline $2001 / 2002$ & 8179 & 5575 & 4186 & 12346 & 5864720 & 1653855 & 7518575 \\
\hline $2002 / 2003$ & 8321 & 4314 & 12647 & 12643 & 6478000 & 1720000 & 8198000 \\
\hline $2003 / 2004$ & 8869 & 6252 & 6143 & 15012 & 7714669 & 3956535 & 11651204 \\
\hline $2004 / 2005$ & 8912 & 6854 & 6989 & 15900 & 7789893 & 4816188 & 12606081 \\
\hline $2005 / 2006$ & 8912 & 7154 & 7100 & 16012 & 8443907 & 5244330 & 13688237 \\
\hline $2006 / 2007$ & 9001 & 7593 & 7409 & 16420 & 9340754 & 5826989 & 15167743 \\
\hline $2007 / 2008$ & 9030 & 7791 & 7564 & 16594 & 9940311 & 6187179 & 16127490 \\
\hline $2008 / 2009$ & 9063 & 8184 & 7655 & 16718 & 999013 & 6218114 & 16208127 \\
\hline $2009 / 2010$ & 9159 & 8735 & 7968 & 17127 & 10237514 & 6370041 & 16607555 \\
\hline $2010 / 2011$ & 9331 & 9523 & 8120 & 17451 & 10749390 & 6688543 & 17437933 \\
\hline $2011 / 2012$ & 9798 & 9941 & 8351 & 18149 & 11416646 & 6893176 & 18309824 \\
\hline $2012 / 2013$ & 9953 & 11932 & 9084 & 19036 & 12120266 & 8467879 & 20588145 \\
\hline
\end{tabular}

Both orthodox and CTC tea are produced and processed in Nepal (Figure 1): orthodox tea gardens are in the mountainous regions of Nepal at an altitude ranging from 3,000 - 7,000 
feet above the sea level. There are six major districts (Ilam, Panchthar, Dhankuta, Terhathum, Sindhulpalchok and Kaski), primarily in the eastern regions of Nepal that are known for producing quality orthodox tea. CTC tea is produced in lower altitudes in the fertile plains of Nepal, which are warm and humid, primarily in the Jhapa district, which is ideal for the production and processing of CTC tea. These gardens need to be well maintained following good production and management practices for quality tea production.

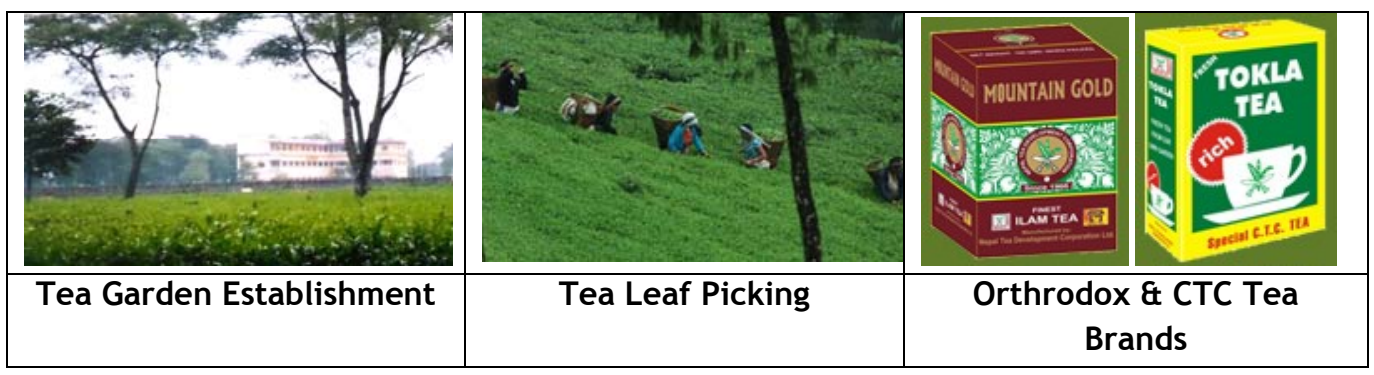

Figure 1.Tea-garden establishment and tea harvesting to consumer markets of CTC and Orthrodox tea

Pest occurrence/incidence : Over millions of insects have been known to exist on this earth, however, only few of them perhaps one percent is considered as pests of crops. Almost all pests have their natural enemies (predators, parasitoids) and moreover, insects play important role in pollination of crops and also provide service to us with their valuable products. Occurrence of different species of insects and mite at three sites is presented in Table 2. Terai and food hills harbored all eighteen pests (seventeen insect species and one mite), while common looper (Buzura suppressaria Guen), red slug caterpillar (Eterusia magnifica Butler) and red spider mite (Oligonichus coffeae Niet) were absent in tea garden during flushing period in mid hills. Regular monitoring of tea gardens in different ecological domain could provide good knowledge of all prevailing pest problems and their natural enemies, and necessary management options to device for eco-friendly pest management.

Table 2. Occurrence of insect pests of tea in terai, foot hill and mid hills of eastern Nepal

\begin{tabular}{|c|c|c|c|c|c|c|c|}
\hline \multirow{2}{*}{ SN } & \multirow[b]{2}{*}{$\begin{array}{l}\text { Common } \\
\text { name }\end{array}$} & \multirow[b]{2}{*}{ Scientific name } & \multirow[b]{2}{*}{ Order } & \multirow[b]{2}{*}{ Family } & \multicolumn{3}{|c|}{ Occurrence } \\
\hline & & & & & Terai & $\begin{array}{c}\text { Foot } \\
\text { hill }\end{array}$ & $\begin{array}{l}\text { Mid } \\
\text { hill }\end{array}$ \\
\hline 1 & $\begin{array}{l}\text { Common } \\
\text { looper }\end{array}$ & $\begin{array}{l}\text { Buzura suppressaria } \\
\text { Guen }\end{array}$ & Lepidoptera & Geometridae & 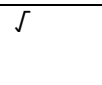 & S & - \\
\hline 2 & Red & Eterusia magnifica & Lepidoptera & Zygaenidae & r & r & - \\
\hline
\end{tabular}




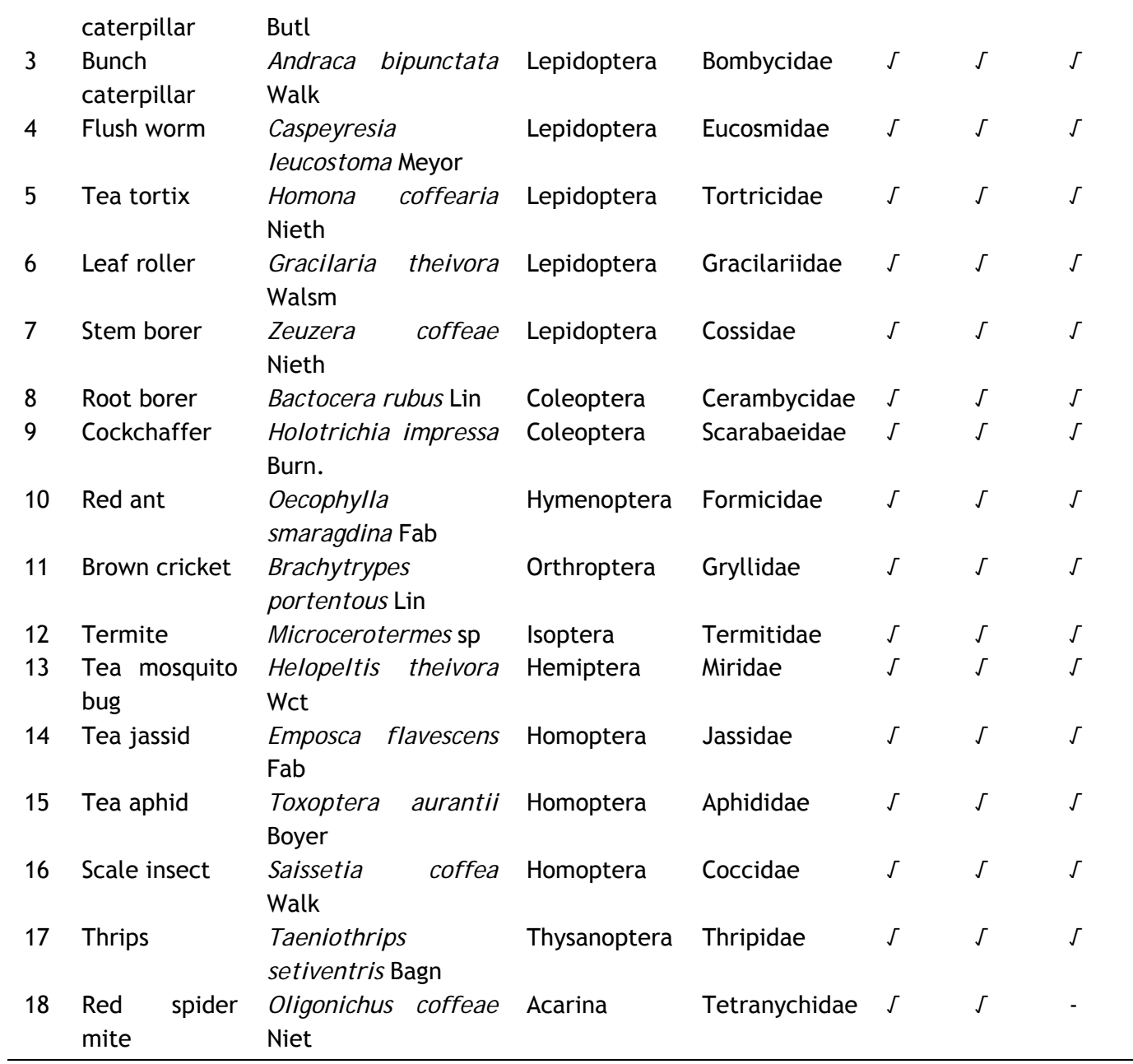

Based on their feedings on different plant parts, the pests were categorized into three major groups, i.e. leaf, stem and root feeders (Table 2). Almost all pests (thirteen insect species and one mite species) showed their presence and preference to leaves feeding. Four species, i.e. stem borer (Zeuzera coffeae Nieth), cockchafer (Holotrichia impressa Burn.), red ant (Oecophylla smaragdina Fab) and tea mosquito bug (Helopeltis theivora Wct) were found feeding on stems and six species, i.e. stem borer (Zeuzera coffeae Nieth), root borer (Bactocera rubus Lin), cockchafer (Holotrichia impressa Burn.), red ant (Oecophylla smaragdina Fab), brown cricket (Brachytrypes portentous Lin) and termite (Microcerotermes sp) harbored feeding on roots (Table 2). Along with insect pests some important natural enemies of the pests are shown in Figure 2 and 3. 
Tea plants are subjected to attack by many pests species and also kept in balance by their natural enemies. According to Chen and Chen (1989), 1034 species of arthropods, 82 species of nematodes, 1 algal and 350 fungal diseases associated with tea plants globally.

Table 2. Incidence of insect pests to different parts of tea plant in eastern Nepal

\begin{tabular}{|c|c|c|c|c|c|c|c|}
\hline \multirow[t]{2}{*}{ SN } & \multirow{2}{*}{$\begin{array}{c}\text { Common } \\
\text { name }\end{array}$} & \multirow[t]{2}{*}{ Scientific name } & \multirow[t]{2}{*}{ Order } & \multirow[t]{2}{*}{ Family } & \multicolumn{3}{|c|}{ Pest incidence } \\
\hline & & & & & Leaf & Stem & Root \\
\hline 1 & $\begin{array}{l}\text { Common } \\
\text { looper }\end{array}$ & $\begin{array}{l}\text { Buzura suppressaria } \\
\text { Guen }\end{array}$ & Lepidoptera & Geometridae & 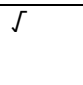 & - & - \\
\hline 2 & $\begin{array}{l}\text { Red slug } \\
\text { caterpillar }\end{array}$ & $\begin{array}{l}\text { Eterusia magnifica } \\
\text { Butl }\end{array}$ & Lepidoptera & Zygaenidae & 厂 & - & - \\
\hline 3 & $\begin{array}{l}\text { Bunch } \\
\text { caterpillar }\end{array}$ & $\begin{array}{l}\text { Andraca bipunctata } \\
\text { Walk }\end{array}$ & Lepidoptera & Bombycidae & J & - & - \\
\hline 4 & Flush worm & $\begin{array}{l}\text { Caspeyresia } \\
\text { leucostoma Meyor }\end{array}$ & Lepidoptera & Eucosmidae & 厂 & - & - \\
\hline 5 & Tea tortix & $\begin{array}{l}\text { Homona coffearia } \\
\text { Nieth }\end{array}$ & Lepidoptera & Tortricidae & 厂 & - & - \\
\hline 6 & Leaf roller & $\begin{array}{l}\text { Gracilaria theivora } \\
\text { Walsm }\end{array}$ & Lepidoptera & Gracilariidae & s & - & - \\
\hline 7 & Stem borer & Zeuzera coffeae Nieth & Lepidoptera & Cossidae & - & 厂 & r \\
\hline 8 & Root borer & Bactocera rubus Lin & Coleoptera & Cerambycidae & - & - & 厂 \\
\hline 9 & Cockchaffer & $\begin{array}{l}\text { Holotrichia impressa } \\
\text { Burn. }\end{array}$ & Coleoptera & Scarabaeidae & - & r & s \\
\hline 10 & Red ant & $\begin{array}{l}\text { Oecophylla } \\
\text { smaragdina Fab }\end{array}$ & Hymenoptera & Formicidae & J & 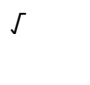 & s \\
\hline 11 & Brown cricket & $\begin{array}{l}\text { Brachytrypes } \\
\text { portentous Lin }\end{array}$ & Orthroptera & Gryllidae & 厂 & & s \\
\hline 12 & Termite & Microcerotermes sp & Isoptera & Termitidae & - & - & 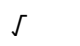 \\
\hline 13 & $\begin{array}{l}\text { Tea mosquito } \\
\text { bug }\end{array}$ & $\begin{array}{l}\text { Helopeltis theivora } \\
\text { Wct }\end{array}$ & Hemiptera & Miridae & r & r & - \\
\hline 14 & Tea jassid & $\begin{array}{l}\text { Emposca flavescens } \\
\text { Fab }\end{array}$ & Homoptera & Jassidae & 厂 & - & - \\
\hline 15 & Tea aphid & $\begin{array}{l}\text { Toxoptera aurantii } \\
\text { Boyer }\end{array}$ & Homoptera & Aphididae & 厂 & - & - \\
\hline 16 & Scale insect & Saissetia coffea Walk & Homoptera & Coccidae & s & - & - \\
\hline 17 & Thrips & $\begin{array}{l}\text { Taeniothrips } \\
\text { setiventris Bagn }\end{array}$ & Thysanoptera & Thripidae & s & - & - \\
\hline 18 & $\begin{array}{l}\text { Red } \\
\text { mite }\end{array}$ & $\begin{array}{l}\text { Oligonichus coffeae } \\
\text { Niet }\end{array}$ & Acarina & Tetranychidae & 厂 & - & - \\
\hline
\end{tabular}

Many natural enemies of tea tree insect pests haven been reported from neighboring countries, China and India. Weiliang (1991) reported 173 species of insects of tea tree pests 
belong to 29 families in 8 orders including 55, 19, 39 and 51 species of Coleoptera, Hemiptera, Diptera and Hymenoptera, respectivety, from Yunnan Province, China India, Similarly, Das et al. (2010) from India reported 94 species of predators and 33 species of paasitoids of tea insect pests. Such long term detail studies are need to record prevailing pests and their bioagents in tea gardens in Nepal. Eco-friendly management of the pests and conservation of such natural enemies following integrated approach help to maintain healthy tea garden and produce high quality tea.
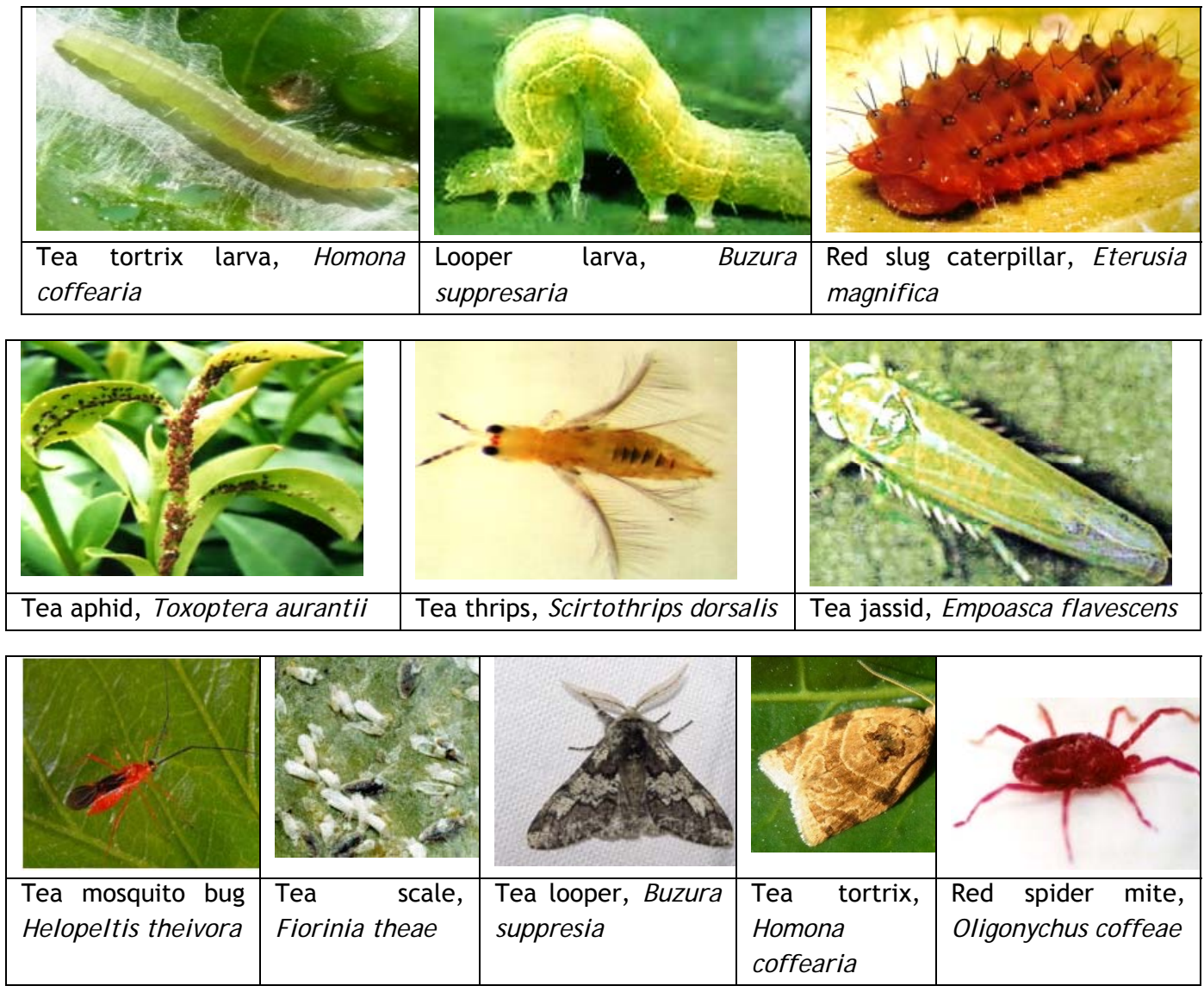

Figure 2. Some insect and mite pests of tea

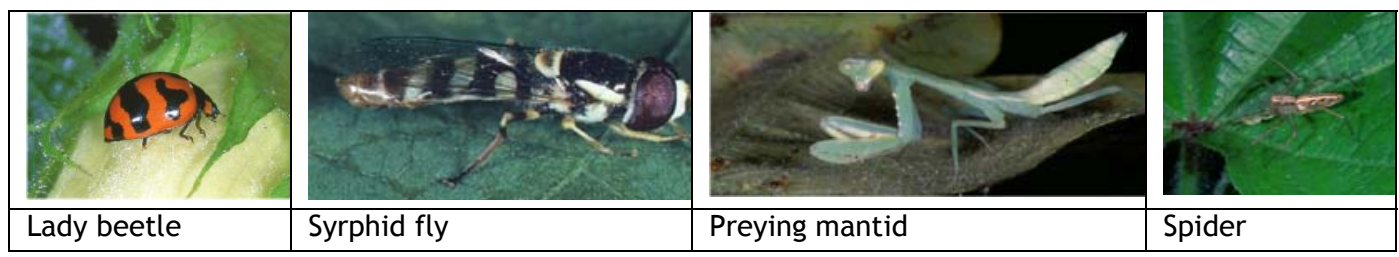

$-193-$ 


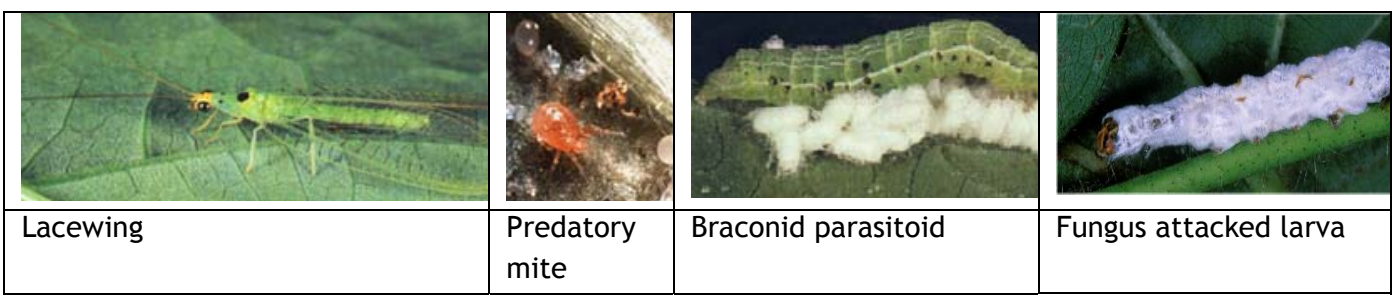

Figure 3. Some natural enemies of tea insect and mite pests

Pest and pesticide management: The methods used to protect tea garden from pests consist of field sanitation, cultural practices including healthy saplings, mechanical means, biological agents and judicious use of agro-chemicals and integrated pest management (IPM). But for immediate protection, use of chemicals is the most preferred choice of the farmers. Pesticide use in tea in general is said to be several times higher than in other crops. Even then, productivity trend in 83 tea estates spreading over 35,423 ha in three agro-climatic regions of Northeast India showed a decline of productivity from 17-20 years of age irrespective of cultivars and agro-climatic conditions. In the surveyed area in eastern parts of Nepal, more than 2 out of 3 heard about IPM. But in practice, there was none of the farmers adopting IPM in their field even in surveyed eastern tea areas of Nepal (Koirala, 2011).

Pesticide application: Annual import of pesticide in Nepal was 345 tons (a.i.) consisting of $33.25 \%$ insecticides, $48.35 \%$ fungicides, $15.49 \%$ herbicides, $2.37 \%$ rodenticides, $0.034 \%$ biopesticides and $0.50 \%$ others, respectively, valued at NRs. 374.90 million ( $\$ 4$ million) per anum (Sharma et al., 2012). Among the agricultural commodity tea receives highest pesticide after cotton in Nepal (Thapa, 2003). Majority of farmers have been spending pesticides worth of more than NRs 9000 on their tea garden per annum (Koirala, 2011). The recent information gathering showed that tea farmers have been applying different pesticides to reduce pest incidence in their tea garden (Table 3). Koirala (2011) also reported nearly more than 20 different types of pesticides being used in tea garden. However, after the initiation of IPM on tea in Jhapa and Ilam farmers are aware of pesticide pollution and trying to explore alternative means of pest management in their tea gardens. Though farmers have been using WHO Cass II or safer pesticides, they are practicing cocktail preparation of two or more than two pesticides without knowing their compatibility, which is of serious concern to health and environment. 
Table 3. Farmers applying different types of pesticides against target pests in their tea gardens

\begin{tabular}{|c|c|c|c|c|}
\hline SN & Common name & Trade names & $\begin{array}{l}\text { WHO } \\
\text { Class }\end{array}$ & Target insect pests \\
\hline 1 & $\begin{array}{l}\text { Emamectin } \\
\text { benzoate }\end{array}$ & $\begin{array}{llllll}\text { Chemdoot } & (5 \%) & \text { SG, } & \text { Kingstar } & (5 \%) & \text { SG, } \\
\text { Proclaim-5 SG } & & & & \end{array}$ & II & $\begin{array}{l}\text { Common looper, } \\
\text { Red slug caterpillar }\end{array}$ \\
\hline 2 & Flubendiamide & Fame-480 SC (39.35\% ) SC & II & $\begin{array}{l}\text { Bunch caterpillar, } \\
\text { Flush worm }\end{array}$ \\
\hline 3 & Imidaclorprid & 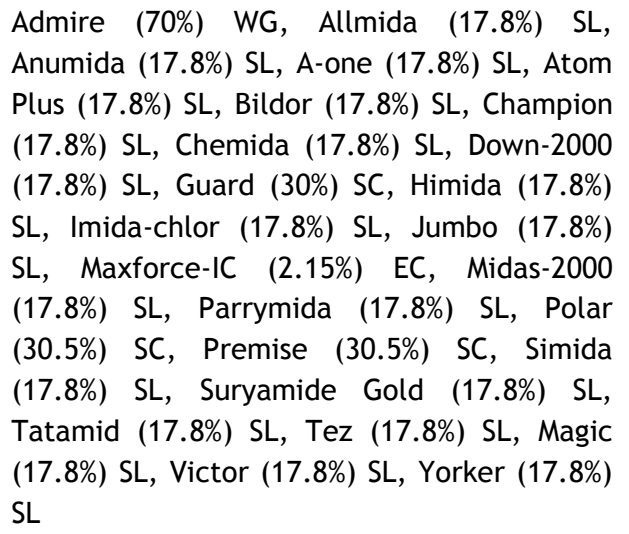 & II & $\begin{array}{l}\text { Tea tortrix, } \\
\text { Cockchafer, Stem } \\
\text { borer, Root borer, } \\
\text { Scale insects, thrips }\end{array}$ \\
\hline 4 & Thiamethoxam & $\begin{array}{l}\text { Actara (25\%) WG, Arrow (25\%) WG, Black } \\
\text { Diamond (25\%) WG, Caper (25\%) WG, Maxima } \\
(25 \%) \text { WG, Molara (25\%) WG, Pele }(25 \%) \text { WG, } \\
\text { Renova v, Slayer ( } 25 \%) \text { WG }\end{array}$ & II & Leaf roller \\
\hline 5 & $\begin{array}{l}\text { Metarhizium + } \\
\text { Imidaclorprid }\end{array}$ & $\begin{array}{l}\text { Cocktail spray mixing any of trade marks of } \\
\text { Imidaclorprid with Metarhizium }\end{array}$ & - & Termites \\
\hline 6 & $\begin{array}{l}\text { Imidaclorprid } \\
+ \\
\text { Thiamethoxam } \\
+ \text { Hexathyzox }\end{array}$ & $\begin{array}{l}\text { Cocktail sprays mixing more than two } \\
\text { pesticides }\end{array}$ & - & $\begin{array}{l}\text { Tea mosquito bug, } \\
\text { Tea greenfly, Tea } \\
\text { aphid, Thrips }\end{array}$ \\
\hline 7 & $\begin{array}{l}\text { Insecticide + } \\
\text { Magic Stick }\end{array}$ & Insecticide with adhesive materials & - & Scale insects \\
\hline 8 & Dicofol & $\begin{array}{l}\text { Coloner }+S(18.5 \%) \text { EC or servo oil and } \\
\text { acaricide }\end{array}$ & II & Tea mites \\
\hline
\end{tabular}

Source: PRMS, 2013; EC=Emulsifiable concentrate, SC= Soluble concentrate, SG= Soluble Granule, $\mathrm{SL}=$ Soluble concentrate, $\mathrm{WG}=$ Water Dispersible Powder,

According to survey conducted by Koirala (2011), $40 \%$ of tea farmers applied pesticides ten times or more in one crop cycle. Pesticides are poisonous substances and they are to be handled with extreme care. On the basis of 'acute toxicity, pesticides are grouped into four 'hazard categories (Table 4). The label shows a square (set at an angle of $45^{\circ}$ ) divided into 
two triangles. The lower triangle colored according to the hazard category and the upper triangle show the symbols of toxicity.

Table 4. Hazard categories of plant protection formulations

\begin{tabular}{llllllll}
\hline SN & $\begin{array}{l}\text { Classification } \\
\text { Of pesticides }\end{array}$ & Signal word & Group & \multicolumn{2}{c}{$\begin{array}{c}\text { LD50 per kg body } \\
\text { weight } \\
\text { Solid }\end{array}$} & Color Code & Signal on \\
Container
\end{tabular}

Again, based on the types of pesticides used, various signs and symptoms of diseases/disorders have been observed among the tea growers and the relative risk also observed to be high. Lack of adoption of adequate protective measures were noticed to have increased the declining state of the health of farmers (Sharma, et al., 2012; Dey et al., 2013). For instance, in India, during the period of April 2010 to March 2011, a total 15321 samples were analysed by $2 \mathrm{l}$ participating laboratories. Residues were found in 1044 (6.8\%) samples, out of which the residues were detected above maximum residue (MRL) in 188 (1.2\%) samples (DACMA. 2011). Farmers in Assam often used pesticides ranging from high to extremely hazardous categories, like Organochlorides, Organophosphates, Carbamates and synthetic pyrethroids.

Some of the signs and symptoms felt by farmers with a higher prevalence were excessive sweating (31.8\%), stinging /itching eyes (33.8\%), dry/sore throat (20.5\%), skin redness/white patches $(32.8 \%)$, numbness/muscle weakness/muscle cramps $(30.5 \%)$ chest pain/burning sensation (34.1\%), excessive salivation (33.1\%) (Dey et al., 2013). To reduce the pesticide environment pollution and MRLs on tea product, safer pesticides as a last resort have to be considered based on threshold of tea pests rather than routine application of pesticides. These days microbial and botanical bio-pesticides have gained popularity against different insect pests of various crops (Roy and Muraleedharan, 2014; Mukhopadhyay and Chakraborty, 2008).

In Nepal, MRLs of fresh vegetables has been started in Kathmandu valley, however, exportable commodities, like, tea, coffee, honey have not received such serious concern. 
The MRLs of pesticides in tea have changed recently (Table 5). This has created strong pressure to the farmers on tea garden pest management and compelled them to move for safer and bio-pesticide materials.

Table 5. Selected tea tolerances/MRLs in western countries

\begin{tabular}{llccc}
\hline SN & Active Ingredient & US Tolerance $(\mathbf{p p m})$ & EU MRL $(\mathbf{p p m})$ & Codex MRL $(\mathbf{p p m})$ \\
\hline 1 & Acetamiprid & 50.0 & $0.1^{*}$ & none \\
2 & Bifenthrin & 30 & 5 & 30 \\
3 & Buprofezin & 20 & $0.05^{*}$ & $30(2013)$ \\
4 & Carfentrazone-ethyl & 0.10 & $0.02^{*}$ & none \\
5 & Chlorantraniliprole & 50.0 & $0.02^{*}$ & none \\
6 & Chlorpyrifos & none & $0.1^{*}$ & 2 \\
7 & Clothianidin & 70 & 0.7 & 0.7 \\
8 & Deltamethrin & none & 5 & 5 \\
9 & Dicofol & 50.0 & 20 & $40(2013)$ \\
\hline & & Source: William, $2013 ; *$ Indicates the lower limit of analytical detection.
\end{tabular}

Integrated Approach: The integrated management of tea was initiated with the government effort during II-Phage of the National IPM Program (2009-2013) in Nepal (Thapa, 2013). Tea growers participated in IPM-FFS in tea (Figure 4). During their training, farmers learn the principles of IPM: i) grow healthy crops, ii) observe the field regularly, iii) understand the agro-ecosystem and conserve natural enemies, and iv) farmers become expert. Then they apply all sound practices of IPM and practice accordingly. In fact, tea IPM in farming community (Farmers groups) relies on community tea plantation planning for IPM technology based production, processing and marketing with good record keeping in green book by each tea farmer to prove the traceability complying all their rules and regulations and code of conduct with truthful labeling of the product strictly following Local Good Agricultural Practices (LGAP) developed by the government for safe quality tea production. The production and income from tea has been found higher with quality in IPM practiced tea garden than in FP tea garden. This is also a transitional phase to transfer traditional chemical farming to eco-rich organic farming. 


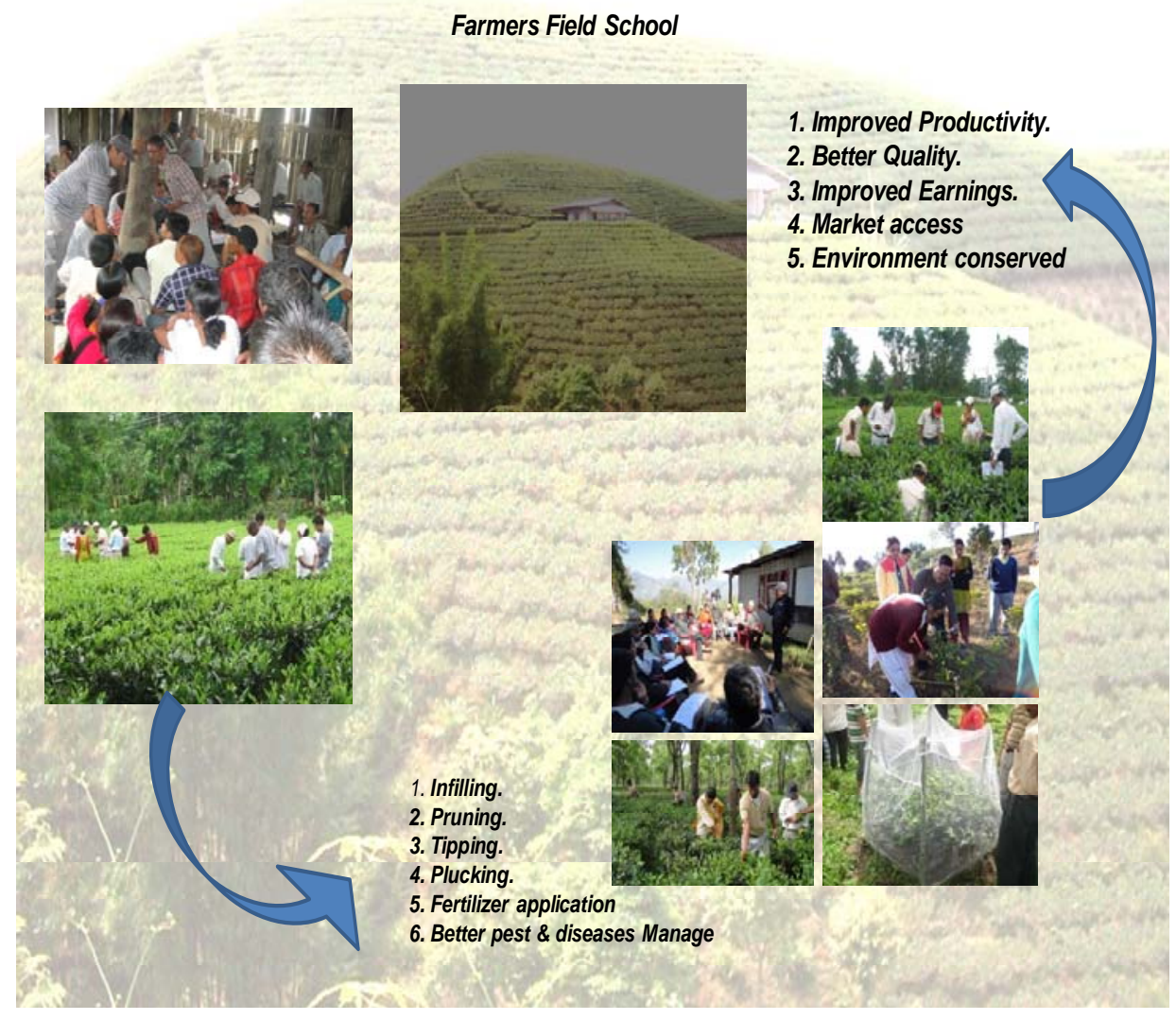

Figure 4. Participating farmers in IPM-FFS training and learning process

A comparative of organic and conventional farming system at two planting fields conducted in Tea Plantation in Malaysia clearly showed the advantage of organic farming system resulting in significantly higher soil pH (4.14 vs 3.38$)$, leaf length $(15.14 \mathrm{vs} 13.19 \mathrm{~cm})$, leaf width $(7.33$ vs $5.58 \mathrm{~cm})$ as well as major polyphenol content in tea shoot (172.42 vs $107.03 \mathrm{mg} / \mathrm{g}$, while, conventional farming system revealed disadvantage of producing higher levels of ammonium (332.4 vs $45.2 \mathrm{~kg} / \mathrm{ha}$ ) and nitrate (39.0 vs $19.2 \mathrm{~kg} / \mathrm{ha}$ ) content in soil as compared to organic farming system (Chin et al., 2010).

Even after considering all above factors, tea cultivation and quality is affected by global warming. Climate change is expected to have a significant impact on global tea production (ITC, 2014). The changes in temperatures and rainfall not only altere the taste, aroma, and potential health benefits of the popular beverage but also the lives of farmers who grow 
tea for a living. According to Hazarika (2011) from the 100 years of tea research, environmental impact is likely to take a serious threat in large areas especially old tea bushes. Field monitoring and light trap, which has often been used in the ecological studies of insect pests in agro-ecosystems are highly useful to alert regarding pest activity among farmers that may be effectively utilized to schedule different pest-management operations. Available recent technology can help development of super clone with most of the attributes which would sustain for long time, at least 40-50 years. Therefore, integrated approach of tea garden management following good practices and quality tea production is necessary to sustain this commodity and compete quality tea produce in the international market.

\section{CONCLUSIONS}

Important tea insect pests and mites have been recorded in tea garden in different ecological domains of eastern Nepal. In fact, sustainable tea cultivation mainly relies increasingly on alternatives to conventional chemical insecticides including farmers' indigenous practices for pest management with bioagents' conservation that are environment-friendly, resilience to climate and reduce the amount of pesticide in tea garden and residues in made tea. It is important to maintain a good balance between technological innovation and its applicability to tea industry and main focus should be for the solutions to ecological imbalance being caused by biotic and abiotic factors, and TeaIPM takes care of all the concerned issues to sustain tea production in Nepal.

\section{REFERENCES}

Chin, F.S., T.Y. Ho, K.P. Chong, M.B. Jalloh, and N.K. Wong. 2010. Organic versus conventional farming of tea plantation. Borneo Science 26: 19-26.

DACMA. 2011. Monitoring of Pesticide Residues at National Level (Annual Report 2010-11. Department of Agriculture and Cooperation, Ministry of Agriculture, India.

Das, S., S. Roy and A. Mukhopadayay. 2010. Diversity of arthropod natural enemies in the tea plantaintations of North Bengal with emphasis on their association with tea pests. Current Science 99 (10): 1457-1463.

Dey, K.R., P. Choudhury and B. K. Dutta. 2013. Impact of pesticide use on the health of farmers: A study in Barak valley, Assam (India). Journal of Environmental Chemistry and Ecotoxicology 5(10): 269-277. Available on: http://www.academicjournals.org/JECE

Hazarika, M. 2011. 100 years of tea research - a journey of pride. Science and Culture 77 (9-10):347352.

ITC. 2014. Mitigating climate change in the tea sector. ITC, Geneva, Switzerland.

Jain, N. K. (ed.). 1999. Global advances in tea science. Aravali Books International (P) Ltd., New Delhi, India. 882pp.

Koirala, P. 2011. Study on pests and pesticide residue in tea in Jhapa and Illam districts of Nepal. Central Department of Zoology, Tribhuvan University, Nepal. 
Mamun, M.S.A and M. Ahmed. 2011. Prospect of indigenous plant extracts in tea pest management. International Journal of Agriculture Research Innovations and Technology 1 (1-2): 16-23.

Mukhopadhyay, D.D.A. and R. Chakraborty. 2008. A noble bacterial pathogen (Enterobacter sp) isolated from the leaf roller Caloptilia theivora of tea of Darjeeling foothills. World Journal of Microbiology and Biotechnology 24:2727-2729.

NTCDB. 2014. Tea statistics. Nepal tea and coffee development board, Kathmandu, Nepal.

PRMS. 2013. Registered pesticides application booklet (Nepali). Pesticide Registration and Management Section, Plant Protection Directorate, Harihar Bhawan, Lalitpur, Nepal.

Reid, A. 2014. Impact of climate change on tea quality (2014, January 20) retrieved 5 January 2015 from http:// phys. org/news/2014-01-impact-climate-tea-quality.html

Roy, S., and N. Muraleedharan. 2014. Microbial management of arthropod pests of tea: current state and prospects. Applied Microbiology and Biotechnology 98 (12): 5375-5386.

Sharma, D. R., R. B. Thapa, H. K. Manandhar, S. M. Shrestha and S. B. Pradhan. 2012. Use of pesticide in Nepal and impacts on human health and environment. J. Agric. \& Environ. 13:6774.

Sinha, M. P. 2010. World tea production and manufacturing. Wishwell Publisher, New Delhi, India.

TBI. 2014. Plant protection code: Policy on usage of plant protection formulations in tea plantations of India. Tea Board of India, West Bengal, India.

Thapa, R. B. 2013. National integrated pest management program in Nepal" (UTF/NEP/059/NEP) Consolidation and Institulization Phage-II. Technical Report submitted to FAO, December 2013, Kathmandu, Nepal.

Thapa, R.B., 2003. Pesticide pollution and integrated pest management. In: F. P. Neupane (ed.) Integrated Pest Management in Nepal. Proc. Natl. Sem. IPM in Nepal, 25-26 Sept. 2002. HIRI, Ktm, Nepal. pp. 175-194.

Thapa, R.B., 1997. An overview of pesticide pollution in Nepal. Nepalese Hort., 1(1):31-39.

Yongming, Yu. 1999. Agro-technology of tea in China. In: N.K. Jain (ed.) Global Advances in Tea Science. Aravali Books International (P) Ltd., New Delhi, India. pp. 481-500.

Weiliang, L.G.X. 1991. A check list of natural enemy insects of tea tree pests from Yunnan. Department of Plant Protection,Yunnan Agricultural University, Kunming, China. Available on : http://en.cnki.com.cn/Article_en/CJFDTOTAL-YNLX199101014.htm

William, R. 2013. MRLs from international beverage company perspective. Global Scientific and Regulatory Affairs, Atlanta, Georgia, USA.

Zhongmao, Z. 2013. Pesticide residue in tea and its risk assessment. Tea Research Institute, Chinese Academy of Agricultural Sciences, Hangzhou, China. 